Fall 10-1-2012

\title{
The Arrest of Caleb Williams: Unnatural Crime, Constructive Violence, and Overwhelming Terror in Late Eighteenth-Century England
}

\section{Gary Dyer}

Cleveland State University, g.dyer@csuohio.edu

Follow this and additional works at: https://engagedscholarship.csuohio.edu/cleng_facpub

Part of the Literature in English, British Isles Commons

How does access to this work benefit you? Let us know!

Publisher's Statement

This work remains under copyright @ 2014 Eighteenth-Century Life, Duke University Press, doi: 10.1215/00982601-1672817, http://muse.jhu.edu.proxy2.library.illinois.edu/journals/eighteenthcentury_life/v036/36.3.dyer.html

\section{Recommended Citation}

Dyer, Gary, "The Arrest of Caleb Williams: Unnatural Crime, Constructive Violence, and Overwhelming Terror in Late Eighteenth-Century England" (2012). English Faculty Publications. 5.

https://engagedscholarship.csuohio.edu/cleng_facpub/5

This Article is brought to you for free and open access by the English Department at EngagedScholarship@CSU. It has been accepted for inclusion in English Faculty Publications by an authorized administrator of EngagedScholarship@CSU. For more information, please contact library.es@csuohio.edu. 


\title{
The Arrest of Caleb Williams: \\ Unnatural Crime, Constructive Violence, and Overwhelming Terror in Late Eighteenth-Century England
}

\author{
Gary Dyer \\ Cleveland State University
}

Beginning in the 1770s, the twelve justices of the three central English common law courts - the King's Bench, the Common Pleas, and the Exchequer-ruled repeatedly that blackmailing a man by threatening to accuse him of "unnatural practices" constituted highway robbery. The judges' arguments focused on the terror inflicted by this form of blackmail. Sodomy was a capital crime, yet, even if prosecution was unlikely, the social stigma of irregular sexuality meant that a supposed sodomite had to fear for his reputation and his station in society. Because the repercussions of being thought a sodomite were even more terrifying than death, it followed, the judges reasoned, that if someone extorted payment by wielding such an accusation, then the threat provided the compulsion that in common law was one of robbery's necessary components, and the blackmailer was guilty of a hanging offense. Inflicting terror was the key issue, and therefore, the blackmailer's actions were no less criminal if his allegations were true.

This essay explores these developments in English criminal law and argues that awareness of them reveals how closely late eighteenth-century "paranoid gothic" literature, exemplified here by William Godwin's novel 
Things as They Are: or, The Adventures of Caleb Williams (1794), engages with other, nonliterary discourses of "terror" that were ubiquitous at the time. ${ }^{1}$ Eve Kosofsky Sedgwick has defined "paranoid gothic" as narrative in which a man "not only is persecuted by, but considers himself transparent to and often under the compulsion of, another male." 2 Paranoid gothic fiction was largely an innovation of the Romantic period, and Caleb Williams may be Romantic literature's preeminent exploration of mutual paranoia, insofar as two men persecute each other and compel each other's acts. ${ }^{3} \mathrm{Caleb}$ 's curiosity impels him to pry into the past of his melancholy and secretive employer, Ferdinando Falkland, whom Caleb knows was suspected of murdering Barnabas Tyrrel. After Caleb's inquiries finally drive Falkland to confess his guilt, Falkland, fearing that Caleb is poised to betray him, frames Caleb for theft, a capital crime. Since Sedgwick's Between Men appeared in 1985, it has become a truism that paranoid gothic literature deals with same-sex eroticism, often by dramatizing contests concerning the boundary between the homosocial and homosexual, but scholars have slighted the persistence with which gothic paranoia and same-sex sexuality were associated throughout English culture of the later eighteenth century, and associated in English law.

I shall argue that the twelve judges' decisions regarding sodomy blackmail are a covert presence when Falkland accuses Caleb of a crime that in the law was closely akin to this form of blackmail. Even though Falkland's secret transgression was, literally, murder, Caleb's uncovering of Falkland's secret resembles the uncovering of a history of sodomy. In England, at the end of the eighteenth century, one of the most terrifying threats to a man's personal reputation, or "character," was the threat of being accused of sodomy; although being called a mass murderer might be one of the most terrifying accusations we can imagine, according to the judges and others, only one allegation inspired a terror that was so overwhelming that nothing else mattered, and that was the threat of a sodomy allegation. If paranoid gothic discourse is that which shows a man suffering another man's "compulsion," then the twelve judges were simultaneously historians and facilitators of Romantic-era gothic paranoia. Law and literature are often more intricately related than is generally recognized, and the law itself could be a paranoid gothic text, depending upon and actively encouraging scenarios in which men put each other in fear. Caleb Williams can exemplify paranoid gothic fiction so well in part because it evokes the paranoid gothic narratives circulating in English society, particularly those found in English 
criminal law. It is testimony to the power of these narratives that Caleb Williams offers no alternative to them: although Godwin, here as elsewhere, critiques his society's obsession with character, he does not demonstrate how to make men's fears for their characters less overwhelming.

\section{Blackmail in Caleb Williams}

Caleb Williams begins with Falkland, a local squire, hiring eighteen-yearold Caleb as a "secretary" (5). Caleb's education might appear too scanty to qualify him as a secretary in the usual sense of the word, but he may fit the original definition of "secretary," a person "who is entrusted with private or secret matters; a confidant; one privy to a secret" (OED). Caleb soon learns that working for Falkland involves keeping his secrets, though not really being entrusted with them. After a few months, Caleb walks into a room and surprises his employer, who evidently has been searching a trunk. Falkland accuses Caleb of spying on his "privacies." That evening, Falkland places five guineas in Caleb's hand without saying a word, and, as Caleb records, "I easily understood that secrecy was one of the things expected from me" (8). Caleb soon hears the story of how Falkland was once suspected of murdering his rival Tyrrel. Falkland "thought every calamity nominal but a stain upon his honour" (103), and he can imagine no stain worse than suspicion that he did away with someone. Caleb finds himself driven to discover whether his employer is guilty, and he compulsively tests Falkland, for example, by alluding to events that might make him think of Tyrrel's death. When Falkland, in his role as a justice of the peace, inquires into a murder among local peasants, his distress convinces Caleb of his guilt. When a fire breaks out in Falkland's house and confusion reigns, Caleb impulsively attempts to break open Falkland's mysterious trunk because his desire to learn what it contains is "too powerful to be resisted" (132). Just then, Falkland enters. He grabs a pistol, and, for a moment, seems poised to shoot Caleb dead.

After the fire is under control, Falkland swears Caleb to secrecy and confesses that he killed Tyrrel and allowed two other men, a father and son named Hawkins, to be hanged for the crime. He makes clear that he would like to kill Caleb, but the memory of murdering Tyrrel makes him tremble at the thought of killing again, and, furthermore, he might get caught this time. So, he must confide in Caleb, telling him that it would be "better to 
trust you with the whole truth under every seal of secrecy, than to live in perpetual fear of your penetration or your rashness" (136). Falkland tells Caleb that he must remain his servant forever, forever despised and feared. When Caleb flees, Falkland frames him for stealing, and Caleb is held to stand trial for a crime that could send him to the gallows. After escaping jail, Caleb spends years as a fugitive, and even when he is no longer pursued, reports of his supposed crime, spread by Falkland's agents, make him a pariah.

Connotations of sodomy are everywhere in Caleb Williams, as critics have noted: Falkland sometimes looks or acts as sodomites were believed to do-he can be seen as foreign and effeminate, for example. Caleb seems more likely to excel as Falkland's catamite than as his secretary, and the men's relations are dominated by metaphors of penetration and mutual pleasure. ${ }^{4}$ Yet Caleb's relations with Falkland suggest sodomy in a more subtle and more significant way, evoking the concealment and the mutual fear surrounding it. English law referred to sodomy as "a crime not fit to be named," and Falkland's horror at murdering Tyrrel and framing the Hawkinses for his crime renders his transgressions unspeakable, much as sodomy was unspeakable: he is guilty of what Caleb calls "secret and atrocious offenses" (274), and against him Caleb makes what Falkland knows are "the most odious charges" (305). ${ }^{5}$ When Falkland's half brother Mr. Forester says to Caleb that "where there is mystery, there is always something at bottom that will not bear the telling" (148), he inadvertently suggests that mystery may be a sign of the crime not fit to be named. Just as some crimes exceed the power of language, some allegations exceed human tolerance: Falkland regards the "imputation" that he killed Tyrrel as "ten thousand times worse to me than death"; this crime is "the most black that any human creature is capable of perpetrating," and he tells the tribunal inquiring into Tyrrel's death that its judgment will be powerless "to restore to me my unblemished reputation, to obliterate the disgrace I have suffered, or to prevent it from being remembered that I have been brought to examination upon a charge of murder" $(100-01){ }^{6}$

Although critics have recognized the connotations of same-sex sexuality, they have not related them to the novel's overt themes and purposes as they would if they took into account the legal decisions pertaining to sodomy blackmail. As we shall see, Falkland's fear for his reputation resembles that which, according to the twelve judges, overwhelmed a man suspected of sodomy, fear a man felt because legal vindication was power- 
less to restore his good name. Furthermore, the third section of this essay will contextualize Caleb's own anxieties using James Stephen's and John Thelwall's accounts of their roles in scandals from the 1780s, accounts that provide invaluable testimony about the repercussions of exposing sodomitical behavior. First, however, we need to recognize how the interactions of master and servant in Caleb Williams suggest blackmail, even though Caleb has not demanded money. When Falkland gives Caleb five guineas (no small sum), Caleb profits from Falkland's need for concealment just as a blackmailer would profit, although the only secret Caleb knows at this point is that his employer seems to have one. Similarly, when Falkland says that "I will benefit you in respect of fortune," these benefits resemble blackmail payment (136), and when Falkland's servant Thomas, long afterward, gives Caleb $£ 20$ unsolicited, this, too, can look like hush money (286-87). In each instance, Falkland appears to submit to blackmail even though Caleb has not actually blackmailed him. Caleb depicts himself as anything but a blackmailer, and even though his tactics in investigating Falkland may resemble a spy's, he tells himself and the reader that he will never become an "informer" $(13), 13)$. The only motivation he acknowledges is curiosity, his "ruling passion" (118), but a cynical reader may scoff, inferring that Caleb is driven by the motive that drives most spies, money. Even if this is not Caleb's "real" motivation in the novel, his explanation of his behavior can sound dubious.

Twice when Caleb is a fugitive he encounters people who suspect that his actual offense was in knowing Falkland's secrets. The leader of the band of thieves, Mr. Raymond, tells the others that he has concluded from Caleb's story that Falkland framed Caleb because he "had been perhaps a little too inquisitive in his master's concerns," and maybe Caleb "had been trusted with some important secrets" (224). When Raymond suggests that Caleb was trusted with Falkland's secrets, he practically implies that Falkland confessed to something, and when Raymond suspects that the valuables Caleb took from his master were actually valuable information, he is only one step away from suspecting blackmail. Soon afterward, Caleb, disguised as a beggar, overhears a conversation between two laborers that suggests blackmail. The laborers are discussing the notorious "Kit" Williams, and one of them deduces that the story in circulation is one-sided and incomplete. He doubts that Caleb robbed Falkland, notes that Falkland was once suspected of murder, and then gives his theory of the case. He explains that Kit 
threatened to bring his master to trial at the 'size all over again, and so frightened him, and got money from him at divers times. Till at last one squire Forester, a relation of t'other, found it all out. And he made the hell of a rumpus, and sent away Kit to prison in a twinky, and I believe he would have been hanged; for when two squires lay their heads together, they do not much matter law, you know; or else they twist the law to their own ends, I cannot exactly say which. (236)

Though the laborer accepts the prevailing wisdom that Falkland is "as innocent as the child unborn," he insists on dissecting the story he has heard, which looks like blackmail to him, perhaps because his humble station has made him alert to the ways powerful men twist the law to their own purposes. The laborer conjectures that the money Caleb reportedly stole from Falkland he actually extorted from him, and that Falkland and Forester, unwilling to draw attention to Tyrrel's murder, transformed the extortion into theft. Because Falkland was suspected of murder, the laborer assumes that Falkland's blackmailer wielded a murder accusation, but a different allegation would suggest itself to someone in the 1790s who witnessed Falkland's terror and bore in mind the view of blackmail taken by the twelve judges.

\section{Sodomy Blackmail as Robbery}

Deliberating upon the cases of Rex v. Thomas Jones (1776), Rex v. James Donnally (1779), and Rex v. Daniel Hickman (1783-84), the twelve judges focused on the damage that rumors of unnatural practices could wreak on a man's "character." In the definitive case, Daniel Hickman was tried for robbery after he extorted three guineas from John Miller by threatening to proclaim him a sodomite, and the jury convicted Hickman. When the judges reviewed the case in 1784, they upheld the verdict and clarified the doctrine they had put forward in Rex $v$. Jones and Rex $v$. Donnally. ${ }^{7}$ After observing that robbery by definition involved "such a degree of force or terror, as to induce the party unwillingly to part with his property," they ruled that the law cannot distinguish between "real or expected violence to the person," on the one hand, and "injury to the character," on the other, because "to most men the idea of losing their fame and reputation is equally, if not more terrific than the dread of personal injury." Furthermore, the judges implied, a man's character would be ruined if he were accused of what they melodramatically termed "the greatest of all crimes." 8 Because of 
the twelve judges' decisions, many offenders went to the gallows over the next few decades, and in 1833, when William Attrell was hanged for extorting five shillings, The Times reported that "from the frequency of offences of this description, it is said the Government has signified that, whenever a clear case is made out, the execution of the offender must inevitably follow." Because a perpetrator had to take money or valuables in order to be guilty of robbery, the only event that was certain to save a blackmailer's neck was, ironically, his victim's failure to pay. In 1805, Colonel Robert Passingham and John Edwards were convicted of conspiring to extort money and other favors from George Forrester by claiming they would tell the authorities he was guilty of unnatural practices, and it was pointed out that if Forrester had acquiesced, then the defendants would be guilty of a capital felony rather than a misdemeanor. ${ }^{10}$

The term blackmail was not used in its most familiar sense before 1840, but the practice today called blackmail was common in Britain in the later eighteenth century, and blackmail over "unnatural crimes" appeared to be on the rise. Rex $v$. Jones and the related rulings were preliminary steps in the emergence of blackmail as a distinct legal concept. ${ }^{11}$ Draconian sentences could not eliminate such an easy and lucrative crime, however, and upper-class men continued to fall victim. In the 1820 treason trial of the Cato Street conspirators, the defense, aiming to impugn the testimony of a government spy, Thomas Dwyer, produced a witness who testified that Dwyer had suggested they make some quick money by going to Hyde Park and accusing wealthy men of making sexual overtures. ${ }^{12}$ In 1822, the foreign secretary, Lord Londonderry, formerly Lord Castlereagh, killed himself when he was blackmailed after being tricked into entering a male brothel. ${ }^{13}$ The twelve judges assumed that homoeroticism and paranoia were inseparable when they acknowledged why victims of sodomy blackmail were so quick to hand over their money and so apt to keep quiet about how they had been taken advantage of. Yet the crucial point is not that the judges missed a chance to restrain homophobic hysteria (who in eighteenthcentury England seized such opportunities?), but rather that they made the mutual harassment essential to paranoid gothic into a permanent part of the common law.

Although a man's fear for his reputation could, by itself, constitute compulsion, the courts declined to extend this principle to blackmail that involved allegations other than sodomy, and in Rex v. Knewland (1796), Justice Ashhurst, speaking on behalf of the twelve judges, explained why, 
voicing explicitly the distinction that had been generally assumed since Rex v. Hickman twelve years earlier. James Knewland and Nathaniel Wood had forced payment from Sarah Wilson by threatening to charge her with theft, but even though theft was punishable by death, as were murder, forgery, and scores of other offenses, accusing someone of any of these crimes lacked the impact of a sodomy accusation. In the case of sodomy, "The bare idea of being thought addicted to so odious and detestable a crime," Ashhurst wrote, was "a punishment more terrible, both in apprehension and reality, than even death itself" (Leach, 2:845-46). No other kind of blackmail constituted robbery because, in the twelve judges' view, no other crime was as heinous as sodomy, no other stain on a man's reputation was as indelible, and no other kind of extortion inspired terror that eclipsed even the fear of death. In 1805, one of Ashhurst's colleagues, Sir Nash Grose, presiding over Passingham and Edwards's sentencing, called allegations of sodomitical propensities "a species of slander under which the mind of man felt more misery than it was capable of feeling under any other, and compared with which his property was of little value, or even life" (Whole Trial, 23). This threat to a man's reputation was worse than death, while no threat to a woman's reputation could be worse, whatever fiction and drama suggested to the contrary.

One reason suspicion of sodomy was unique was that the law's remedies were inadequate. Knewland and Wood threatened to bring Wilson before a magistrate for theft, and "an innocent person need not in such a situation be apprehensive of any danger," according to Ashhurst (Leach, 2:846). Extorting money by threatening to prosecute for stealing, or treason, or murder, for that matter, cannot be robbery because the threat has no teeth. With sodomy, in contrast, confidence that justice will triumph provides no consolation because the allegation alone injures a man's character beyond repair. ${ }^{14}$ Of course, the widespread belief that wealthy men routinely escaped punishment for their sexual transgressions was one reason why an acquittal was unlikely to convince the public that the allegation was false. Mere suspicion of this sexual proclivity, according to the ruling in Rex v. Donnally, will "blast the fairest fame, and ruin for ever the brightest character" (Leach, 1:235). The judges' assumptions in this regard were generally accurate, given their society's hostility toward unconventional sexuality and resistance to discussing it rationally. In 1816, Lord Byron, aware that a rumor marked him as a sodomite, said that "even to have such a thing said is utter destruction $\&$ ruin to a man $\&$ from which he never can recover." ${ }^{15}$ 
In 1833, Charles Baring Wall, MP, was acquitted on charges of making advances to another man, a policeman, but Charles Greville commented in his journal that "nobody can be plunged into such mire without smelling of it more or less ever after, and what is perhaps the worst, carrying about with them the consciousness of the stink." ${ }^{16}$ The permanence of the stink encouraged blackmail, because a man accosted by a blackmailer had huge incentives not only to hand over his money, but also to remain silent afterward. Wall's problems were aggravated by reports that his friends had attempted to bribe his accuser to recant; they testified that they believed the policeman's goal was extortion, and so they tried to get him to show his hand. ${ }^{17}$

The twelve judges were obviously fascinated by the effect of sodomy blackmail on the victim's mind. They required two steps to establish that merely threatening to label a man a sodomite qualified as "putting in fear": in 1779 , they ruled in Rex $v$. Donnally that sodomy blackmail was robbery even if the blackmailer refrained from physical force, and then, five years later, they ruled in Rex $v$. Hickman that it was robbery even if the victim did not anticipate any kind of physical violence, even if the danger he envisioned jeopardized his character alone. At James Donnally's trial, the presiding judge, Sir Francis Buller, reserved for his eleven brethren and himself the question of whether the defendant's crime constituted robbery - the question, specifically, of whether Donnally had inflicted upon Charles Fielding the requisite "degree of violence, or inspired that degree of fear." The judges said yes: when a man is blackmailed with this threat, "Such a terror is impressed upon the mind as does not leave the party a free agent," so that "in order to get rid of that terror he delivers his money"; there is a "reasonable fear of danger, caused by the exercise of a constructive violence" (Leach, 1:233). ${ }^{18}$ In certain similar cases prior to Donnally's, notably Rex v. Jones, "Some actual violence was proved, as taking and seizing by the arm or collar," but "this circumstance did not make any material distinction" (Leach, 1:237; cf. Rex v. Jones, 1:166). Donnally's violence was "constructive" insofar as the jury inferred the existence of force that had the same effect as physical violence, and the force then became indistinguishable from physical violence in the law's eyes (Leach, 1:236). Fielding's concern for his character was not critical in this case because he also feared he might be "dragged through the streets" (Leach, 1:234), but Hickman's victim, John Miller, five years later, feared only for his reputation (Leach, 1:312), and the twelve judges affirmed that this, too, was robbery. 
Yet, although Rex v. Hickman was the first case to come before the judges in which physical danger was not a factor, the principle at work in its purest form in this ruling had guided their thinking since Rex v. Jones in 1776. Buller's charge to Donnally's jury reveals that he believed Jones's case had established that an imperiled reputation was enough. ${ }^{19}$ When the judges deliberated over the Donnally case, Lord Chief Justice Mansfield said, "with great energy," that this form of blackmail "was a specious mode of robbery of late grown very common, invented by fraud to evade the law." ${ }^{20}$ In Mansfield's view, sodomy blackmail had always been robbery, even if courts had been slow to recognize it as such and criminals had been quick to exploit the oversight. The fear was key, and fear of being associated with sodomitical practices overwhelmed the victim regardless of the precise allegation, regardless of whether it might lead to criminal charges, and regardless of its truth. ${ }^{21}$ While the judges in Rex v. Donnally acknowledged the possibility of mob violence, they largely ignored the legal threat to the blackmail victim's physical safety: a blackmailer who informed a magistrate that the sexual act had been completed imperiled his victim's life as efficiently as if he brandished a pistol. The law also disregarded the medium by which the imputation might be spread; Hickman said he would take Miller before a magistrate, but his threat would be essentially the same if he said he would tell Miller's employer or accuse Miller in a pamphlet.

Beginning with Rex v. Donnally, the victim's mental state became crucial, which it had not been when Thomas Jones grabbed hold of Mitchell Newman's arm; correspondingly, the victim's testimony regarding his expectations became the law's method for gauging how any sensible man would react to the defendant's provocation-gauging, that is, if the man in the dock had "impressed" terror on his victim's mind. "No passion so effectually robs the mind of all its powers of acting and reasoning as fear," Burke wrote in his Philosophical Enquiry into the Origin of our Ideas of the Sublime and Beautiful (1757), and the judges said that Charles Fielding's "terror" was so great that he ceased to be "a free agent" and paid Donnally because his impulse was "to get rid of that terror." 22 Although the victim's terror must be "reasonable" (Leach, 1:233), according to Rex v. Donnally, meaning that the threat would probably overwhelm any reasonable man in comparable circumstances, the terror suspended a man's reason, and his enslavement to terror was essential to the crime. Moreover, if inspiring terror was the decisive issue, then the truth of the imputation had to be ruled out as a defense; 
permitting a blackmailer to defend himself with such evidence would be like permitting a highwayman to demonstrate that his victim was unusually vulnerable to bullets. The judges' rulings led inevitably to the conclusion that even a sodomite could prosecute if blackmailed. This consequence was clear as early as 1790, when prosecution counsel William Garrow acknowledged to an Old Bailey jury that "it could make no difference in the case, if you should be persuaded that a man had been guilty of the filthy practice which this extortion states." 23 The blackmail victim's fear per se became the essence of robbery when the twelve judges decided, in Rex v. Reane (1794), that the victim had to be afraid at the instant he surrendered his money. ${ }^{24}$ Late eighteenth-century courts deferred continually to Justice Foster's 1755 dictum stating that the only evidence of violence or fear required in a robbery trial was evidence of "those Circumstances of Violence or Terror which in Common Experience are likely to induce a Man to part with his Property for the Safety of his Person." ${ }^{25}$ A circumstance of terror was generally taken to mean a circumstance that would inspire terror (see, for example, Blackstone, 4:242), but in Rex $v$. Reane, the judges changed course and defined robbery in terms of the victim's emotions rather than his predicament. The judges' persistent fascination with the victim's terror was presumably determined not only by the fact that men's reputations were so vulnerable to rumors of unnatural practices, but also by the broader cultural interest in the workings of terror. The sublime is produced, according to Burke's Philosophical Enquiry, by "whatever is in any sort terrible, or is conversant about terrible objects, or operates in a manner analogous to terror." When danger or pain "press[es] too nearly," however, it cannot provide "delight," or the sublime, and such presumably was the case with the victim of sodomy blackmail; yet, while sublime delight was denied to the victim, it was available to spectators like judges and juries (13-14).

Because of Godwin's fascination with crime, he is almost certain to have known that blackmail over sodomy was legally capital robbery. When the British Critic claimed that Godwin had misrepresented points of criminal procedure in Caleb Williams, he responded that he knew as much as writing the novel required him to know, and he contrasted his detractor's expertise in legal principles with the knowledge of actual criminal cases available in the "Newgate Calendar, or any of the most common records." ${ }^{26}$ In 1832, Godwin recollected that while composing Caleb Williams he was "extremely conversant" with The Nerugate Calendar, which he cites in a foot- 
note in the novel, and the edition of this compendium that he consulted contains a detailed account of Rex v. Donnally. ${ }^{27}$ Godwin presumably was also familiar with such "common records" as the Old Bailey Proceedings (published several times a year) and the reports of trials in London newspapers. During the ten years Godwin lived in London prior to beginning Caleb Williams, the Old Bailey Proceedings and The Times covered several sodomy blackmail trials. In December 1790 and January 1791, George Platt, James Templeman, Philip Roberts, and William Smith were convicted and sentenced to death for highway robbery, and Philip Davis was convicted in November 1792, three months before Godwin commenced writing his novel. ${ }^{28}$ Moreover, Godwin would have paid attention when he heard of such cases: the law's elevation of "character," for example, would attract the notice of the man who wrote in An Enquiry Concerning Political Justice (1793) that "virtue cannot possibly be measured by the judgment and good pleasure of any man with whom we are concerned." ${ }^{29}$ Godwin may never have joined the few who wrote directly and overtly about sodomy blackmail, but his writings in the 1790s repeatedly address aspects of it, such as the obsession with reputation or the infliction of terror, and no one ought to be surprised if sodomy blackmail seems to loom over the novel that he designed to illustrate "the modes of domestic and unrecorded despotism, by which man becomes the destroyer of man" ([1]). Sodomy blackmail epitomizes and brings together themes that obviously are central to Caleb Williams, and one might even go as far as to suggest that the same-sex eroticism critics have noticed in the novel is present largely because of the theme of blackmail. In any case, Godwin's awareness of sodomy blackmail can be inferred from the crucial events in Caleb Williams that in the 1790s connoted this offense more than they connoted any other.

Rex v. Donnally and related cases reveal that proscribed sexuality offered Godwin the best example of terror on behalf of one's character, and he could hardly have adopted this example any more fully, given the restrictions on representing sexuality in published fiction. When Godwin devised the plot of Caleb Williams, he struggled to imagine a cause "adequate to account for the impulse that the pursuer should feel, incessantly to alarm and harass his victim, with an inextinguishable resolution never to allow him the least interval of peace and security," a cause that would impel a man to deprive another "of peace, character, and credit, and have him for ever in his power" (Godwin, Fleetwood, 8-9). Although the cause Godwin finally selected was "a secret murder," a different secret suggests 
itself when we treat the twelve judges' assumptions as typical of their society: Falkland's terror evokes sodomy more than it evokes murder. Falkland says that the thought that people suspect he killed Tyrrel is "ten thousand times worse to me than death" (101), but, as we have seen, the nation's highest judges had ruled that only one imputation was worse than death, and it was not murder. Although gentlemen of Falkland's stature were seldom prosecuted for sodomy, such prosecutions did occur, one of which, in 1806, resulted in the hanging of a man worth $£ 60,000 .{ }^{30}$ The prospect that terrifies Falkland is not a trial, however, but disgrace, and he becomes terrified to a degree that, according to the law, is excessive, unless it is because he anticipates being labeled a sodomite. Since Falkland turns the tables on Caleb, so that Caleb is the one charged with a capital offense, Falkland's terror over murder can be confidently translated into terror over sodomy. Falkland's persecution of Caleb evokes specifically intimidation concerning sexual transgressions; blackmailing a man was not a capital offense unless the blackmailer threatened to accuse him of sodomy. ${ }^{31}$

The fabricated crime for which Caleb is detained differs from robbery (and from sodomy blackmail) in this critical respect: the victim's fear plays no role. Falkland says he has been "robbed" ([164]), Caleb refers to the accusation as robbery $(175,193,275)$, and other people call it such (236, $268,286)$, but the supposed offense does not fit the definition of robbery. If Caleb, as alleged, took advantage of the fire to break into Falkland's trunk and steal hundreds of pounds in banknotes and other items, and Falkland did not notice the loss until later (see 164-68), then the crime would best be classified in common law as larceny from the house (Blackstone, 4:239-40), though a sixteenth-century statute, $21 \mathrm{Hen}$. VIII, c. 7 (1529-30), decreed specifically that it was a felony if a servant embezzled goods from his or her master worth forty shillings or more (Blackstone, 4:231). All these crimes were capital offenses, yet, as Blackstone explained, robbery differed from other forms of larceny insofar as it involved "force, or a previous putting in fear," either of which "makes the violation of the person more atrocious than privately stealing" (4:242). ${ }^{32}$ If Caleb is held for common law larceny or statutory stealing from his master, neither charge would imply that he put his victim in fear. The reader knows that Caleb terrified Falkland, yet Falkland not only conceals this, but also frames Caleb for a crime that, by definition, cannot involve terror. Falkland accuses Caleb of taking his possessions, but not of scaring him, or even of stealing from him in his presence. By depersonalizing Caleb's theft, he represses his own terror, as if to 
avoid suggesting he has anything to fear and to keep attention away from his vulnerability and its cause.

Falkland's character is stained too easily, stained merely if he is treated as if he were not a gentleman: as his servant Collins observes to Caleb, Falkland experiences being beaten and kicked by Tyrrel as a "disgrace" that is "worse than death" (96). When Collins objects that a person "can only be dishonoured by perpetrating an unjust action" (98), he clearly speaks for the author, who wrote in Political Justice that "true honour is to be found only in integrity and justice" (2:519; see also 1:178). If Godwin disapproved of the obsession with "character," he would likely disapprove as strongly of the emphasis on character governing the judges' rulings in Rex v. Donnally and Rex v. Hickman. Indeed, some of Falkland's statements read like parodies of the reputation-worship that these rulings exemplify; he thinks that being pummeled by a bully is worse than death, and suspicion of killing the bully is ten thousand times worse. Confronted regarding Tyrrel's death, Falkland exclaims, "Great God! what sort of a character is that which must be supported by witnesses?" (101). Anti-empiricism like his has the practical disadvantage of making any stain on his character ineffaceable. These stains are as permanent as rumors of unnatural practices, as though Falkland transforms all allegations into allegations of sodomy. Unfortunately for Caleb, Falkland is not the only person who sees character this way, and when Caleb's last remaining ally, Laura, tells him that "true virtue refuses the drudgery of explanation and apology" (299), she guarantees that Caleb cannot vindicate himself. Indeed, as we shall see, Caleb's experiences in the final volume of the novel suggest that the twelve judges were wrong: sodomy's stigma was not unique.

\section{Mutual Intimidation: The Dangers of Accusing a Gentleman}

As this analysis of Caleb's history might suggest, conflicts between social classes played a central role in people's conceptions regarding sodomy blackmail. The eighteenth and nineteenth centuries often understood sexual deviance in terms of class, representing sodomites as aristocratic libertines who took advantage of their station to coerce boys or men who were less fortunate. Supposedly, they even utilized the law regarding blackmail as a tool of seduction: in The Phoenix of Sodom (1813), Robert Holloway told of a servant who was sentenced to Newgate for threatening to reveal his 
master's "Sodomitical practices" if he was not paid his wages, and Holloway charged that "it seems to have come to this, that if a young man will not submit to Sodomy and hold his tongue, he must be hanged" (36). Even if seduction was not their aim, elite men allegedly were apt to use the law to intimidate and discredit anyone who might attribute unnatural practices to them, to "twist the law to their own ends," as the laborer in Caleb Williams says.

James Stephen's narrative of the 1781 Edward Onslow scandal, written in the 1820 s, dramatizes how men of limited means might be overwhelmed by fear for their characters when allegations of sexual irregularity generated countercharges of blackmail. ${ }^{33}$ On May 2nd, at an art exhibition at Somerset House, Onslow, MP for Aldeburgh, grabbed Felix McCarthy indecently three times. When McCarthy struck him, Onslow fled, and McCarthy had to complain about Onslow's conduct in order to explain his own. In the words of Holloway, writing thirty-two years later, "The prejudice against an Irish adventurer, as Macarty [sic] was termed, gave the transaction an interpretation that conveyed an idea that his intention was to extort money from the nobleman" (38). When McCarthy was deposed before magistrate Sir Sampson Wright, Lord Onslow repeatedly interrupted to threaten McCarthy with "the most exemplary Punishment for having formed a Villainous Conspiracy against his Sons Character and life." ${ }^{34}$ The Onslows were on the verge of having McCarthy and his supporters prosecuted for such a conspiracy.

Stephen promptly put his reporting skills to work for his friend McCarthy, and his account of these "strange occurrences," published in the Morning Post the next day, emphasized the magistrate's flagrant bias against Onslow's accuser. When the story appeared, "The Town rang with it." ${ }^{35}$ But Stephen had involved himself more than was prudent: realizing that he was being followed and watched, he feared that his double life (he had a mistress) would become public knowledge. His anxiety deepened when he learned that the witnesses who vouched for McCarthy's story had dubious reputations; they were, Stephen implies, the kind who might fabricate an accusation. Although his efforts on McCarthy's behalf were limited, he knew that "indirect and circumstantial evidence is much allowed and favoured" in conspiracy cases, and Onslow's allies "would naturally cast the net of accusation as comprehensively as possible" (Stephen, 352-53). Paranoia about the elite was in the air, and Stephen's anxiety was aggravated by "many appalling anecdotes of men who had been sacrificed in similar cases ... to save the guilty Great and their families from infamy" 
(352). The anecdotes that disturbed Stephen suggested that sodomy was the nadir toward which aristocratic corruption progressed, and that prosecution was the aristocrat's favorite preemptive strike. The predicament of the working-class sodomite has no place in accounts like Stephen's. Although Stephen's main problem solved itself when Edward Onslow confessed to his father and fled to France, and the Onslow family dropped their plan of prosecuting, Stephen remained wary of being associated with blackmail. Lord Onslow, eager for his son's behavior to be forgotten, offered to pay $\mathrm{McCarthy}$ if he gave up on prosecuting Wright, the magistrate who arguably had obstructed justice by trying to intimidate Edward Onslow's accusers. Against Stephen's advice, McCarthy accepted $£ 500$, and when McCarthy was "publicly attacked for dropping the prosecution," Stephen was "thankful that [his] name was not at all implicated in that part of the case” (358-59). He needed to distance himself when McCarthy's actions invited suspicion that blackmail had been his goal all along.

A gentleman who had to fear being labeled a sodomite (which would mean almost any gentleman) could seldom be certain who might accuse him or how he might fend off the accusation. In Rex $v$. Jones and subsequent rulings, the twelve judges gave such a man a new weapon to use, or abuse; now the wealth and social standing that made him an ideal target also helped him intimidate actual or potential blackmailers. Appearing to know a gentleman's secrets, whatever their nature, had always been dangerous, and now many people became even more vulnerable to false accusations of blackmail. They might suffer simply because one of their superiors was fearful; just as a gentleman was always susceptible to a servant accusing him of sexual irregularities, a servant was always susceptible to his employer accusing him of blackmail. To be situated so as to know your master's secrets, sexual or not, puts you at risk. If men who were suspected of unnatural practices felt overwhelming terror, they could also inflict it on men they persecuted. Contemplating the conspiracy charge, Stephen discovered that "Even the being acccused [sic] of, and tried for, such a crime was inexpressibly dreadful to my feelings," and he imagined that, if convicted, he "would commit suicide in the face of the Court to prove my sense of honor at least by my desperation" (353). Though the twelve judges at roughly this time felt certain sodomy was the only imputation worse than death, Stephen knew of another: conspiring to blackmail a gentleman by associating him with sodomy. This imputation outweighed death even though someone convicted of conspiracy would merely be fined or 
imprisoned. While a man's reputation could not be cleansed once he was suspected of sodomy, the same fate awaited a man suspected of attempting to blackmail someone over sodomy.

Caleb Williams, as if taking into account experiences like Stephen's, goes beyond the twelve judges' rulings by showing how terrifying the imputation of a crime other than sodomy can be. Falkland makes this point to Caleb: "If ever an unguarded word escape from your lips, if ever you excite my jealousy or suspicion, expect to pay for it by your death or worse" (136). When first accused, Caleb foresees repercussions like those the common law judges associated with the imputation of sodomy, and like those Stephen associated with the imputation of sodomy blackmail: Caleb will "be deprived of the benefits of integrity and honour," and he will "forfeit the friendship of every one I have hitherto known, and ... be precluded from the power of acquiring that of others" (173). Stephen thought suicide might be his best defense, and he had far greater resources than Godwin's protagonist. Caleb's prophecy is fulfilled. By choosing ultimately to smear Caleb rather than to pursue charges against him, Falkland consigns him to limbo, and it resembles the limbo of a man who is suspected of unnatural practices but who remains free because the evidence is insufficient, or because his rank protects him. Caleb tells himself that "fair fame" is merely "the jewel of men formed to be amused with baubles" (182), and he says he must "be reduced to derive my satisfaction from myself" (173), but isolation cannot be satisfying for social beings, and his need for companionship torments him.

What future can Caleb expect if Falkland's guilt is established? Onslow's accusers feel no sympathy when he must flee the country, only relief or triumph, but Godwin's friend John Thelwall, writing in the 1790s, revealed how, once a man no longer needs to fear intimidation or retaliation, his terror on his own behalf may give way to horror on behalf of his enemy. In a memoir appended to Poems Chiefly Written in Retirement (1801) Thelwall recorded that when he was working for attorney John Impey in the early 1780s, he suffered "an attack made upon his innocence" by Impey's law partner (Thelwall refers to himself in the third person). The partner, "in consequence of the unreserved indignation with which Thelwall exposed his infamy, and the publicity of a train of similar circumstances, which consequent investigation brought to light, put a period to his existence with a razor"; unlike Lord Onslow's son, a humble attorney could not simply escape into European exile. Thelwall was already disillusioned with 
the law, and the attorney's advances and their consequences "completed Thelwall's disgust," as though they epitomize the repugnant aspects of life in the Inner Temple and the evil endemic to human institutions. ${ }^{36} \mathrm{His}$ account thus suggests that members of Godwin's radical circle stood ready to join the campaign against unnatural practices, which they believed typified the abuses they dedicated themselves to exposing.

In the 1790s, however, Thelwall revealed that exposing "infamy" was more disturbing than his 1801 memoir tried to make it appear. As Michael Scrivener has pointed out, Thelwall fictionalized the episode with the attorney in his novel The Peripatetic (1793), where a character, Wentworth, describes a similar experience. Upon being told of a man who went mad after killing someone even though the death was accidental, Wentworth comments that the "vivid impressions" of "Imagination" will not "always submit to the cool and regular deductions of Philosophy." He recalls his own role in someone's death:

No circumstance of my life ever disturbed my tranquility so long, as having been the innocent cause of a fellow-creature committing the crime of suicide.-Innocent? - I was something more than innocent; for in yielding to the honest indignation of my heart, and exposing the horrid vices of a wretch who had endeavoured to seduce me to a participation of his guilt, I acted according to the dictates of my conscience, and believed myself to be discharging a duty to society. And yet, when the intelligence was brought me, that, to escape from the public infamy I had brought upon him, he had put a period to his existence, I felt a thrilling horror creep through every vein; and scarcely could I close my eyes again for many months, without having my imagination haunted with mangled corses, graves, and charnelhouses, and all the dreadful phantoms of a distempered brain. ${ }^{37}$

Wentworth relies on the same anti-sodomitical clichés as his creator Thelwall-innocence, indignation, infamy—but without Thelwall's apparent complacency. The Peripatetic acknowledges that horror is the likely response: Wentworth could not remain calm and rational while contemplating the results of exposing someone as a sodomite. Whereas in Poems Chiefly Written in Retirement sodomitical advances exemplify the corruption of an institution, in The Peripatetic they are the suicide's sole "vice," and so a radical critique of things as they are would be irrelevant-indeed, that aspect of Thelwall's 1801 account looks like an ex post facto justification for homophobic panic. More important, whereas Thelwall's memoir emphasizes his consistency (he is disgusted by the attorney's advances for 
the same reason he is disgusted by the legal profession), Wentworth meditates on his inner conflict, a conflict between reason and imagination. He is driven by his conscience, his "duty to society," and his "honest indignation," and these motives appear so irreproachable that he was surprised when the man's suicide filled him with "thrilling horror." Reason cannot guard his imagination from visions of "mangled corses, graves, and charnel-houses." Godwin was already writing volume two of Caleb Williams when he began reading The Peripatetic in August 1793; his journal does not suggest that he ever reached Thelwall's third volume, in which Wentworth's narrative appears, but Thelwall may have told Godwin of his experience with the attorney, and may have described his horror much as Wentworth does. ${ }^{38}$

Although Caleb Williams originally ended with Caleb going mad in prison, Godwin quickly substituted a different conclusion, one that recalls Wentworth's experience. When Caleb stands before Falkland and others, having announced he will state his case against his former master, he demurs, wondering how he could have been "so eager, so obstinate in a purpose so diabolical" (320). Falkland then unexpectedly proclaims his own crimes and says that his "name will be consecrated to infamy" (324). He dies three days later. This deus ex machina is inconclusive for much the same reasons as Edward Onslow's flight or the suicide of Wentworth's "wretch." For one thing, the persecuted witnesses do not feel exonerated: Stephen's character remains vulnerable, and although Falkland prophesied that Caleb's conduct "will be for ever admired" (324), Caleb ends up with "no character that I wish to vindicate" (326). But that is not an informer's worst punishment: by exposing Falkland, Caleb horrifies himself. He was his master's "murderer," yet he knows that the pain he inflicted on Falkland was, of course, "a thousand times worse than death." Now Caleb must "endure the penalty of my crime," a penalty akin to the "dreadful phantoms" that beset Wentworth: Falkland's "figure is ever in imagination before me," Caleb writes; "Waking or sleeping I still behold him," and "He seems mildly to expostulate with me for my unfeeling behaviour" (325).

It is a truism that terror was one of the keywords of the 1790s, and just as the literature of gothic paranoia had political undertones, politics partook of the paranoid gothic when competing political alliances exchanged accusations of inflicting terror. Burke, an authority on fear's political functions as well as its aesthetics, was moved in 1791 to call the French Revolutionary government "despots" who "govern by terror," yet some would say the same of the British government. ${ }^{39}$ Caleb Williams was designed 
to examine "the modes of domestic and unrecorded despotism," Godwin explained in the preface, and the novel thereby demonstrated how "the spirit and character of the government intrudes itself into every rank of society" (1). Falkland "preferred to govern me by terror," Caleb observes (145), and his tyranny resembles a king's except that it is exercised "upon a contracted scale" (177). In the second edition of Caleb Williams, published in 1796, Godwin noted that this preface had to be withheld when the book first appeared, in May 1794, because John Thelwall, Thomas Holcroft, and others had just been indicted for treason. "Terror was the order of the day; and it was feared that even the humble novelist might be shown to be constructively a traitor" (2); the British government's persecution of radicals resembled the French Terror from which Burke recoiled. In 1796, after the treason trials had ended in acquittals, Godwin was free to acknowledge that domestic terror in Caleb Williams represents in miniature the terror wielded by Britain's rulers, and free to add that the comparison was validated when the preface had to be suppressed. Caleb remains silent because of his master, Godwin because of the attorney general.

Like any class tensions, the class tensions of knowing sexual secrets translated easily into political tensions; we have seen how readily Thelwall fit the attorney's infamy into a critique of things as they are. In the 1790 s, an observer of current events who had absorbed stories like those James Stephen heard might conclude that prosecuting men who knew about their superiors' sexual transgressions went hand in hand with prosecuting men who challenged the prerogatives of the king, the government, and its officers: these two kinds of prosecution used similar methods and were driven by similar forces. Rex $v$. Donnally and the related rulings would have concerned a radical in the 1790s simply because they relied upon the concept of "constructive" offenses. When Godwin wrote that Caleb Williams might have been found traitorous "constructively," he alluded to the constructive treason with which Thelwall and the others were charged. Whenever law officers or judges introduced such offenses, they invited the charge that they had exceeded their authority, and five months after Caleb Williams appeared, Godwin's Cursory Strictures on the Charge Delivered by Lord Chief Justice Eyre to the Grand Jury mounted a memorable assault on the most controversial offense of this kind, constructive treason, complaining of "new constructions of old statutes, contrary to all law and precedent, and contrary to the security and liberty of the subject." ${ }^{40}$ We can speculate that Godwin would have seen the sodomy blackmail decisions as typical of the 
presumption endemic to the courts, and might have concluded that constructive law was the weapon preferred by despotism in general. ${ }^{41}$

Caleb Williams dramatizes how terror reproduces itself, though it does not show how to halt the process. Indeed, Godwin had a stake in terror. Readers have long recognized that Caleb Williams deals in fictional form with the themes of Godwin's Political Justice, except that it emphasizes grim reality instead of alternatives - "things as they are" instead of things as they ought to be. The recurrent question regarding Godwin's novel is whether its grimness undercuts his utopianism. In regard to terror, Caleb Williams reveals the darker implications of Political Justice, which advocate taking advantage of the fear men feel when their reputations are at risk. In Political Justice, Godwin argued that the public must not be "lulled into torpid tranquillity" by "always hear[ing] the praise of things as they are," and that the obligatory exposure of vice relies upon maintaining fear: "There is no terror that comes home to the heart of vice, like the terror of being exhibited to the public eye," writes Godwin, and "There are many men at present who pass for virtuous, that tremble" at this prospect (2:643-44). Yet, although terror is essential to the surveillance and public exhibition Godwin advocates in Political Justice, in Caleb Williams, terror is revealed as one of the ugliest "things that are." Falkland's haunting of Caleb's imagination, like the wretch's haunting of Wentworth's, demonstrates how the principle that fear of exposure is productive fails to constrain the imagination.

$\infty$

Literary conventions discouraged direct references to sodomy in fiction, necessitating circumlocutions like Thelwall's "infamy" and "horrid vice"; critical readers need to be alert to sodomy's figurative appearances. Tyrrel's murder, I have argued, is substituted for what occurs on the level of connotation, as Godwin replaces the unnameable imputation with a nameable one, murder. Yet, although sodomy, not murder, was the best example of a sublimely terrifying allegation, Caleb Williams reveals that the gothic terror the twelve judges restricted to unnatural practices surrounded other allegations, albeit to a lesser degree: allegations that a person had killed someone or had betrayed his master by stealing. So, while Falkland's killing of Tyrrel represents sodomy, it still represents murder.

The most noteworthy feature of the eighteenth-century reaction against sodomy blackmail is not that it was made a capital offense but 
that it was made robbery, and sodomy blackmail could be integrated into this age-old common law crime only because of the incalculable terror it inspired. To the extent that the terror Falkland experiences and inflicts resembles the terror surrounding imputations of sodomy, Caleb Williams reveals that paranoid gothic cannot be attributed only to novelists and poets, but is championed by the law of the land.

\section{Notes}

1. William Godwin, Caleb Williams [1794], ed. and introd. David McCracken (New York: Norton, 1977). I rely on the Norton edition for all citations to the text, although I will also refer to the Broadview edition for its supplementary materials: Caleb Williams, ed. Gary Handwerk and A. A. Markley (Peterborough: Broadview, 2000).

2. Eve Kosofsky Sedgwick, Between Men: English Literature and Male Homosocial Desire (New York: Columbia Univ., 1985), 91.

3. The most detailed account of paranoia in Caleb Williams, an account emphasizing the role of paranoia in the political conflicts of the 1790s, can be found in Thomas Pfau, Romantic Moods: Paranoia, Trauma, and Melancholy, 1790-1840 (Baltimore: Johns Hopkins Univ., 2005), 131-45.

4. For the fullest analyses of same-sex sexuality in Caleb Williams, see Alex Gold, Jr., "It's Only Love: The Politics of Passion in Godwin's Caleb Williams," Texas Studies in Language and Literature 19 (1977): 135-60, an article Sedgwick praises (Between Men, 116); Robert J. Corber, "Representing the 'Unspeakable': William Godwin and the Politics of Homophobia," Journal of the History of Sexuality 1 (1990): 85-101; and George E. Haggerty, Queer Gothic (Urbana: Univ. of Illinois, 2006), 111-16.

5. For "crime not fit to be named," see William Blackstone, Commentaries on the Laws of England, 11th ed., 4 vols. (London: T. Cadell, 1791), 4:215, who cites a fourteenth-century precedent.

6. Arguably Falkland's murder of Tyrrel itself connotes sodomy: as George Haggerty points out, the secret Caleb uncovers is, after all, a "nocturnal encounter at which Falkland carries his relation with Tyrrel to a physical climax" (Queer Gothic, 115).

7. See Select Cases from the Twelve Judges' Notebooks, ed. D. R. Bentley (London: John Rees, 1997), 8-20, on the procedure by which doubtful points of law that emerged in criminal trials were reserved to be examined by the judges who sat in the three common law courts in Westminster Hall.

8. Thomas Leach, Cases in Crown Law, Determined by the Twelve Judges; by the Court of King's Bench; and by Commissioners of Oyer and Terminer, and General Gaol Delivery; from the Fourth Year of George the Second, 1730. to the Fortieth Year of George the Third, 1800, 3rd ed., 2 vols. (London: Butterworth, and Cadell, and Davies, 1800), 1:313. As Justice Willes explained in Rex v. Donnally, common law had long since established that "to constitute the crime of robbery, three ingredients are necessary"; in addition to "some degree of violence, or putting in fear," the ingredients were "a 
felonious intention, or animus furandi" and "a taking from the person of another" (Leach, 1:231-32).

9. See The Times (11 February 1833): 3. Thomas Jones was hanged. Although some authoritative texts state that Hickman was also executed (see Leach, Cases, 1:313), he was reprieved at the last minute, according to the Morning Chronicle and London Advertiser (28 April 1784): 4. The principle that sodomy blackmail constituted robbery was incorporated into statute law with the passage of 7 and 8 Geo. IV, c. 29, s. 7 (1827).

10. The Whole Trial of Col. Robert Passingham and John Edwards, for a Conspiracy Against George Townshend Forrester, Esq. Barrister, with Intent to Deprive the said George Forrester of his Wife and Property; and Charging Him with Many Unnatural Crimes (London: R. Butters, [1805]), 20.

11. See W. H. D. Winder, "The Development of Blackmail," Modern Law Review 4 (1941): 21-50. On blackmail over sodomy in the eighteenth century, see Netta Murray Goldsmith, The Worst of Crimes: Homosexuality and the Law in Eighteenth-Century London (Aldershot: Ashgate, 1998), particularly 51-53, 55-56, 97-104, and Angus McLaren, Sexual Blackmail: A Modern History (Cambridge: Harvard Univ., 2002), 10-16. On blackmail's role in nineteenth-century fiction, see Alexander Welsh, George Eliot and Blackmail (Cambridge: Harvard Univ., 1985).

12. T. B. Howell, A Complete Collection of State Trials and Proceedings for High Treason and other Crimes and Misdemeanors from the Earliest Period to the Year 1783, with Notes and other Illustrations, 34 vols. (London: Longman, Rees, Orme, Brown, and Green, 1809-28), 33:842.

13. On Castlereagh's suicide, see, in particular, H. Montgomery Hyde, The Strange Death of Lord Castlereagh (London: Heinemann, 1959), 184-87, and Harriet Arbuthnot, The Journal of Mrs. Arbuthnot, 1820-1832, ed. Francis Bamford and the Duke of Wellington, 2 vols. (London: Macmillan, 1950), 1:176-83, 241, 253.

14. A paradox emerges here: the courts recognized that rumors of sodomy were nearly impossible to erase, but when blackmail victims like Miller or Fielding prosecuted, they had to testify in court that a man, albeit an untrustworthy one, had selected them as ripe for such an accusation. Victims had to reveal publicly the imputation they paid to bury.

15. Augusta Leigh to Lady Byron, 17 February 1816, from the Lovelace-Byron Archive 80.27-33, Bodleian Library, University of Oxford, 29v.

16. Charles Greville, The Greville Memoirs, 1814-1860, ed. Lytton Strachey and Roger Fulford, 8 vols. (London: Macmillan, 1938), 2:364.

17. The Times (11 March 1833): 3.

18. For an alternative account of the Donnally case, see [Robert Holloway], The Phcenix of Sodom, or the Vere Street Coterie. Being an Exhibition of the Gambols Practised by the Ancient Lechers of Sodom and Gomorrah, Embellished and Improved with the Modern Refinements in Sodomitical Practices, by the Members of the Vere Street Coterie, of Detestable Memory (London: J. Cook, 1813), 37-38. Holloway claims that Donnally had been having an affair with Charles Fielding.

19. The Annual Register, or a View of the History, Politics, and Literature for the Year 1779, 2nd ed. (London: J. Dodsley, 1786), 200. 
20. Morning Chronicle and London Advertiser (1 May 1779): 2.

21. As a rule, blackmailers asserted simply that their victims had made sexual advances: Jones accused Newman of taking "liberties . . . with his person”; Donnally told Fielding he would inform a magistrate he had made "an attempt to commit an unnatural crime"; Hickman said to Miller, "You know what passed the other night; you are a Sodomite” (Leach, Cases, 1:165, 229, 311).

22. [Edmund Burke], A Philosophical Enquiry into the Origin of our Ideas of the Sublime and Beautiful (London: R. and J. Dodsley, 1757), 42.

23. Rex v. George Platt and Philip Roberts, in The Proceedings of the King's Commission of the Peace, Oyer and Terminer, and Gaol Delivery for the City of London; and also the Gaol Delivery for the County of Middlesex, Held at Justice Hall in the Old Bailey, on Wednesday, the 8th of December, 1790, and the Following Days (London: E. Hodgson, [1790-91]), 62. Angus McLaren misses this essential point in his book Sexual Blackmail, asserting that Rex v. Jones and subsequent decisions meant that "false accusations of sodomy were punishable by death" (14). Not until 1824 did a judge state outright that a sodomite could prosecute successfully: see Justice Littledale, in Rex v. Gardner, Gloucester Assizes, reported in F. A. Carrington and J. Payne, Reports of Cases Argued and Ruled at Nisi Prius, in the Courts of King's Bench and Common Pleas, and on the Circuit: from the Sittings in Michaelmas Term, 1823, to the Sittings after Hilary Term, 1825, 2 vols. (London: S. Sweet and R. Pheney, 1825), 1:479. In 1790, Garrow, uncomfortable with the principle he had described, told the jurors that evidence showing the alleged victim engaged in this "filthy practice" would cast doubt on his testimony against the prisoners because such a man will lie to distract attention from his own offenses (Proceedings of the King's Commission, 62-63).

24. Edward Hyde East, A Treatise of the Pleas of the Crown, 2 vols. (London: J. Butterworth and J. Cooke, 1803), 2:734-36, and Edward E. Deacon, A Digest of the Criminal Law of England; As Altered by the Recent Statutes for the Consolidation and Improvement of It, 2 vols. (London: Saunders and Benning, 1831), 2:1,140-41.

25. Michael Foster, A Report of Some Proceedings on the Commission of Oyer and Terminer and Goal [sic] Delivery for the Trial of the Rebels in the Year 1746, in the County of Surry, and of Other Crown Cases. To Which are Added Discourses upon a Few Branches of the Crown Law (Oxford: Clarendon, 1762), 128. Cf. Rex v. Donnally, in Leach, Cases, 1:233-34.

26. William Godwin, Caleb Williams, ed. Handwerk and Markley (Peterborough: Broadview, 2000), 451-52, quotation at 452. Godwin's rebuttal to the British Critic refers to cases in The Nerwgate Calendar and "Lives of the Convicts."

27. William Godwin, Fleetwood, ed. Pamela Clemit, vol. 5 of Collected Novels and Memoirs of William Godwin, gen. ed. Mark Philp, 8 vols. (London: William Pickering, 1992), 5:11, and Caleb Williams, ed. Handwerk and Markley, 452n. Francis Brightwell's story, according to Godwin's footnote in Caleb Williams, comes from volume 1, page 382 of the "Newgate Calendar" (180n), and the volume and page numbers conform to those of The Malefactors' Register; or, New Newgate and Tyburn Calendar. Containing the Authentic Lives, Trials, Accounts of Executions, Dying Speeches, and Other Curious Particulars, Relating to All the Most Notorious Violaters [sic] of the 
Laws of Their Country; Who Have Suffered Death, and Other Exemplary Punishments, in England, Scotland, and Ireland, from the Commencement of the Year 1700, to the Midsummer Session of Next Year, 5 vols. (London: Alex. Hogg, [1779]); for the account of Donnally's case, see the entry under "Donally" [sic], 5:353-56.

28. For Platt, Templeman, Roberts, and Smith, see The Times (11 December 1790) 4; (13 December 1790): 3; and (15 January 1791): 3-4. See also Proceedings of the King's Commission, 32-39, 60-73, 127-31. For Davis, see The Times (3 November 1792): 3, and "A Barrister at Law," Legal Recreations, or Popular Amusements in the Laws of England, 2 vols., vol. 1 (London: J. Bew, et al., [1792]), 75-77.

29. William Godwin, An Enquiry Concerning Political Justice, and Its Infuence on General Virtue and Happiness, 2 vols. (London: G. G. J. and J. Robinson, 1793), 1:178.

30. A. D. Harvey, "Prosecutions for Sodomy in England at the Beginning of the Nineteenth Century," Historical Journal 21 (1978): 939-48, especially 940.

31. One qualification: sending any blackmailing letter was felonious according to the Waltham Black Act if the letter was unsigned or signed with a fictitious name (see, in particular, Blackstone, Commentaries, 4:144).

32. Although Godwin's characters seem to employ "robbery" as an umbrella term for all varieties of stealing, their practice draws the reader's attention to the "putting in fear" that Falkland has concealed. Caleb does distinguish highway robbery from burglary when he lists his jail-mates who are accused of felonies (178).

33. For general accounts of the Onslow scandal, see The House of Commons, 1754-1790, ed. Lewis Namier and John Brooke, 3 vols. (New York: For the History of Parliament Trust by Oxford Univ., 1964), 3:226-27, and C. E. Vulliamy, The Onslow Family, 1528-1874: With Some Account of Their Times (London: Chapman and Hall, 1953), 222-24. Holloway provides a partisan early nineteenth-century version of the story (Phcenix, 38-39).

34. Felix McCarthy, deposition, National Archives, Kew, KB 1/22/4/2. This deposition and several others were submitted to support the prosecution of Sir Sampson Wright for breach of duty.

35. James Stephen, The Memoirs of James Stephen: Written by Himselffor the Use of his Children, ed. Merle M. Bevington, foreword Canon Charles Smith (London: Hogarth, 1954), 350. Unfortunately, the relevant issues of the Morning Post do not survive.

36. John Thelwall, Poems Chiefly Written in Retirement. The Fairy of the Lake, A Dramatic Romance; Effusions of Relative and Social Feeling: and Specimens of The Hope of Albion; or, Edwin of Northumbria: An Epic Poem (London: R. Phillips and Jas. Ridgeway, 1801), xvii-iii. Thelwall's other account of this incident, in "Mr. John Thelwall," Public Characters of 1800-1801 (London: R. Phillips, 1801), 177-93, especially 185 , is nearly identical to the account in Poems.

37. John Thelwall, The Peripatetic [1793], ed. and introd. Judith Thompson (Detroit: Wayne State Univ., 2001), 339. See Michael Scrivener, Seditious Allegories: John Thelwall and Jacobin Writing (University Park: Pennsylvania State Univ., 2001), 272-73. 
38. William Godwin, journal, vol. 6, Bodleian Library, University of Oxford, Dep. e.201.

39. Edmund Burke, A Letter from Mr. Burke, to the Member of the National Assembly; in Answer to Some Objections to his Book on French Affairs (London: J. Dodsley, 1791), 44.

40. [William Godwin], Cursory Strictures on the Charge Delivered by Lord ChiefJustice Eyre to the Grand Jury, October 2, 1794 (London: D. I. Eaton, 1794), 38. On constructive treason and the politics of terror in the 1790s, see John Barrell, Imagining the King's Death: Figurative Treason, Fantasies of Regicide, 1793-1796 (Oxford: Oxford Univ., 2000).

41. Certainly the concepts of constructive violence and constructive treason were being invoked by some of the same men. Sir Francis Buller presided over Donnally's and Hickman's trials, and he and Sir James Eyre were among the twelve judges who confirmed in each case that sodomy blackmail was robbery; in the 1794 treason cases, Eyre charged the grand jury, and Buller was among the judges in the ensuing trials. (The most notable rebuttal to Godwin, Answer to Cursory Strictures, may have been Buller's work.) Thomas Erskine's fame as a courtroom champion of English liberties made him the obvious choice to be defense counsel in the treason trials, and if the class politics of sodomy blackmail are taken into account, it also makes sense that thirteen years earlier he had represented McCarthy and his allies against the Onslow family. 
Abst r Ac $t$

Gary Dyer, "t he Arrest of c aleb Williams: Unnatural c rime, c onstructive Violence, and Overwhelming t error in Late Eighteenthc entury England"

In the later eighteenth century, the twelve justices of the supreme English common law courts ruled repeatedly that blackmailing a man by threatening to accuse him of sodomitical practices constituted the capital offense of robbery; the judges focused on the overwhelming terror they claimed was unique to this threat. $t$ his legal doctrine is a covert presence in William Godwin's novel Caleb Williams (1794). Ferdinando Falkland, fearing that his secret is about to be revealed by c aleb, accuses him of having "robbed" him, and even though Falkland's secret is literally murder, the mutual persecution and mutual terrorizing that ensue evoke the relation between sodomy and blackmail.

Post-print standardized by MSL Academic Endeavors, the imprint of the Michael Schwartz Library at Cleveland State University, 2015 